\title{
QUALITY LOSS RELATED TO RANCIDITY DEVELOPMENT DURING HORSE MACKEREL (Trachurus trachurus) FROZEN STORAGE
}

Santiago P. Aubourg ${ }^{*}$, Carmen Piñeiro and $\mathrm{M}^{\mathrm{a}}$ Jesús González

Instituto de Investigaciones Marinas (CSIC).

c/ Eduardo Cabello, 6. 36208-VIGO (Spain)

\footnotetext{
* Correspondent: S. P. Aubourg

e-mail: saubourg@iim.csic.es

Fax: + 34986292762
}

Keywords: Horse mackerel, whole fish, fillets, frozen storage, quality, rancidity, sensory analysis, shelf life 


\begin{abstract}
The development of rancidity and its effect on quality loss was studied in frozen horse mackerel (Trachurus trachurus). For that, two different kinds of fish products (whole fish and fillets) were stored at a commercial frozen temperature $\left(-20^{\circ} \mathrm{C}\right)$ for up to 12 months and were compared to samples stored at a much low temperature $\left(-80^{\circ} \mathrm{C}\right)$. Analyses included: lipid hydrolysis (free fatty acid formation) and oxidation (peroxide value, thiobarbituric acid index, fluorescent compounds formation), loss in endogenous antioxidant (alpha-tocopherol), proteins changes (electrophoretic analysis of sarcoplasmic and SDS soluble fractions) and sensory analysis (skin, eyes, gills, flesh odor, consistency, flesh appearance). According to biochemical indices, fillets stored at $-20^{\circ} \mathrm{C}$ showed susceptibility to rancidity development, leading to a shelf life of 1 month, while whole fish at the same temperature were still edible at month 5 . The employment of a low temperature $\left(-80^{\circ} \mathrm{C}\right)$ inhibited the rancidity development leading to good quality (whole fish) and fair quality (fillets) fish products at the end of the experiment. The application of protective treatments specially designed to prevent lipid oxidation is encouraged when commercializing this species in the frozen state.
\end{abstract}

Running Title: Quality and frozen horse mackerel 
In the last few decades, marine foods have captured a great attention from consumer because of a positive role on human health and nutrition $(1,2)$. Marine species are known to give rise to a wide range of products of great economic importance in many countries. However, the fishing industry is actually suffering from dwindling stocks of traditional species as a result of drastic changes in their availability. As a result, fish technologists and fish trade have turned their attention to some unconventional sources of raw material $(3,4)$.

One such species is horse mackerel (Trachurus trachurus), a medium fat species, abundant in the Northeast Atlantic (5). Efforts have been done to utilize it in the manufacture of several products such as smoked (6), canned (7), chilled (8) and frozen (9) fish.

Freezing and frozen storage have largely been employed to retain fish sensory and nutritional properties $(10,11)$. However, marine species have shown a highly unsaturated lipid composition and an important presence of prooxidant molecules that facilitate the development of rancidity $(12,13)$. Under frozen conditions, lipid oxidation compounds are produced and have shown to interact with proteins leading to protein denaturation (14), nutritional losses (15) and modification of electrophoretic profiles of proteins (16), while endogenous antioxidant systems have shown to be partially lost (17).

The present work concerns horse mackerel (Trachurus trachurus) and its commercialization as a frozen product. For that, two different kinds of fish products (whole fish and fillets) were kept frozen at a commercial temperature $\left(-20^{\circ} \mathrm{C}\right)$ and compared to the corresponding controls held at $-80^{\circ} \mathrm{C}$. Analyses included lipid hydrolysis and oxidation damage, endogenous alpha-tocopherol assessment, protein 
electrophoretic profile changes and sensory acceptance. The study was carried out over 12 months of frozen storage, so that much attention could be given to quality changes and, accordingly to the shelf life time.

\section{MATERIALS AND METHODS}

\section{$\underline{\text { Raw fish, sampling and processing }}$}

Fresh horse mackerel (Trachurus trachurus) were obtained in a local market 10 hours after being caught. During this time and until arrival at the laboratory, the fish were kept on ice. The length of the fish was in the range $18-24 \mathrm{~cm}$; the weight was in the range $250-280 \mathrm{~g}$. The fish were divided into two groups. One was directly packaged in polyethylene bags and frozen at $-80^{\circ} \mathrm{C}$, and will be considered as the whole fish product (including head, organs and skin) during the present work. The other group was carefully dressed, filleted by hand, washed with water, packaged in polyethylene bags and frozen at $-80^{\circ} \mathrm{C}$; this group will be considered as the fillet product (deboned but not skinned) during the present work. After 24 hours at $-80^{\circ} \mathrm{C}$, half of the whole fish and half of the fillets were placed at $-20^{\circ} \mathrm{C}$, while the remaining material continued to be kept at $-80^{\circ} \mathrm{C}$. Sampling was undertaken on the raw fish material and at months $1,3,5$, 7,9 and 12 of frozen storage at $-80^{\circ} \mathrm{C}$ and $-20^{\circ} \mathrm{C}$ on both kinds of products (whole fish and fillets) after being thawed overnight at $2^{\circ} \mathrm{C}$. At each temperature and for each kind of fish product, three different batches were considered that were studied separately to achieve the statistical study. 


\section{Sensory analyses}

Sensory analyses were conducted by a taste panel consisting of five experienced judges, according to the guidelines presented in Table 1 (18). Four categories were ranked: highest quality (E), good quality (A), fair quality (B) and rejectable quality (C). Sensory assessment of the whole fish samples included the following parameters: skin, eyes, gills, flesh odor, consistency, and flesh appearance. In the case of fillets, the following attributes were considered: skin, flesh odor, consistency, and flesh appearance.

\section{$\underline{\text { Composition analyses }}$}

Once fish products (whole fish and fillets) were subjected to sensory analysis, the white muscle was separated, minced and homogenized for carrying out the biochemical analyses. Water content was determined by weight difference between the homogenized muscle (1-2 g) and after oven-drying, for $24 \mathrm{hr}$ at $105{ }^{\circ} \mathrm{C}$. Results were calculated as $\mathrm{g}$ water/100 $\mathrm{g}$ muscle. Lipids were extracted from the muscle by the Bligh \& Dyer (19) method. Results are expressed as g lipids/100 g wet muscle.

Sarcoplasmic fraction from muscle proteins was obtained by extraction in a lowionic-strength buffer composed of $10 \mathrm{mM}$ Tris- $\mathrm{HCl} \mathrm{pH} 7.2+50 \mathrm{mM}$ PMSF (pentamethyl sulphonic acid). Samples of $500 \mathrm{mg}$ of muscle were homogenized for $60 \mathrm{~s}$ in $4 \mathrm{~mL}$ of solution buffer, according to Piñeiro et al. (20). Afterwards, extracts were centrifuged at $12,500 \mathrm{rpm}$ for $15 \mathrm{~min}$ in a JA20.1 rotor (J221-M centrifuge, BeckmanCoulter, London, UK) at $4^{\circ} \mathrm{C}$, and the supernatants recovered. The protein concentration in extracts was determined by means of the protein microassay method (Bio-Rad Laboratories Inc. Hercules, CA, USA). A standard curve constructed on bovine 
seroalbumin was used as reference. The extracts were maintained at $-80^{\circ} \mathrm{C}$ until electrophoretic analysis.

Solubilization of muscle protein was also made in a 2\% SDS (sodium dodecyl sulfate) buffer (2\% w/v SDS- 0.1 DTT- $60 \mathrm{mM}$ Tris-HCl, $\mathrm{pH} 7.5)$ using the same conditions mentioned for the sarcoplasmic protein extraction (20), except that before the centrifugation at $4^{\circ} \mathrm{C}$, the SDS extracts were boiled at $100^{\circ} \mathrm{C}$ for $2 \mathrm{~min}$, homogenized for $30 \mathrm{~s}$ and finally maintained at room temperature. The protein content was determined by indirect measuring at $280 \mathrm{~nm}(20)$. SDS extracts were maintained at $-20^{\circ} \mathrm{C}$ until posterior analyses.

\section{Lipid damage indices}

Free fatty acids (FFA) content was determined by the Lowry \& Tinsley (21) method based on complex formation with cupric acetate-pyridine. Results are expressed as g FFA/100 g lipids. Peroxide value (PV) expressed as meq oxygen/kg lipids was determined by the ferric thiocyanate method (22). The thiobarbituric acid index (TBA-i) (mg malondialdehyde/kg fish tissue) was determined according to the Vyncke (23) method. Fluorescence formation (Perkin-Elmer LS 3B) at 327/415 nm and 393/463 nm was studied as described elsewhere $(24,25)$. The relative fluorescence (RF) was calculated as follows: $\mathrm{RF}=\mathrm{F} / \mathrm{F}_{\text {st }}$, where $\mathrm{F}$ is the fluorescence measured at each excitation/emission pair, and $F_{s t}$ is the fluorescence intensity of a quinine sulfate solution (1 microg/ml in $0.05 \mathrm{M} \mathrm{H}_{2} \mathrm{SO}_{4}$ ) at the corresponding wavelength. The fluorescence ratio (FR) was obtained from the lipid extract analysis, according to the following calculation: $\mathrm{FR}=\mathrm{RF}_{393-463 \mathrm{~nm}} / \mathrm{RF}_{327-415 \mathrm{~nm}}$. 


\section{$\underline{\text { Tocopherol assessment }}$}

Tocopherol isomers were analyzed according to the Cabrini et al. (26) method. The presence of the different tocopherol isomers was checked. Only the alphatocopherol isomer was detected in the present horse mackerel samples and its content was expressed as microg / 100g fish muscle.

\section{Protein electrophoretic studies}

Electrophoretic analysis was carried out by means of horizontal commercial SDS-PAGE gels. Samples were mixed with sample buffer according to the Laemmli (27) procedure. Because of their higher resolution and reproducibility, precast polyacrylamide $245 \times 110 \times 1 \mathrm{~mm}$ commercial gels (Excel-Gel SDS Homogeneous $15 \%$, Amersham Biosciences, Sweden) for horizontal electrophoresis were selected. Anode and cathode buffer strips (Amersham Biosciences) were also employed. Electrophoretic studies were performed in a Multiphor II electrophoresis system (Amersham Biosciences) provided with a MultiTemp III refrigerated bath circulator (Amersham Biosciences). Running conditions were $1000 \mathrm{~V} / 40 \mathrm{~mA} / 40 \mathrm{~W}$, at $15^{\circ} \mathrm{C}$ for 165 min. Once the bromophenol blue had reached the anode, gels were fixed and stained by a standard silver staining protocol (Amersham Biosciences). A low molecular weight protein standard (14-94 kDa) from Amersham Biosciences was employed as reference.

\section{$\underline{\text { Statistical analyses }}$}

Data from the different biochemical measurements were subjected to the oneway ANOVA method $(\mathrm{p}<0.05)$; comparison of means was performed using a least- 
squares difference (LSD) method (28). Correlation analyses and Spearman test for nonparametric correlations were also performed (28).

\section{RESULTS AND DISCUSSION}

Water content ranged between 74 and $78 \%$ in all samples. Lipid content ranged between 2.2 and $3.7 \%$ on a wet basis. Differences in both constituents may be explained as a result of fish to fish variation, and not arising from frozen storage conditions (time and temperature) and the kind of fish product (whole fish and fillets). Comparison of the present results with previous research showed a higher water content for horse mackerel than for fattier fish species (sardine) (24) and a lower water content than for leaner fish species (blue whiting, cod and haddock) $(25,29)$, in accordance with an inverse ratio between water and lipid matter.

The protein content extracted with low ionic strength buffer was included in the rang 2.5-3.5 (g/100g wet muscle). Small variations in its content could be explained as fish to fish differences and not arising from technological conditions.

\section{Lipid hydrolysis}

In the present study, the FFA content of the raw material (Table 2) was similar to that of fatty fish species (tuna, sardine) $(24,30)$ and lower than that of lean fish species (blue whiting, haddock, cod) $(25,29)$.

Hydrolysis developed gradually at $-20^{\circ} \mathrm{C}$ in both kinds of products, so that a good correlation value with time was obtained $\left(\mathrm{r}^{2}=0.94\right.$ and $\mathrm{r}^{2}=0.89$, for whole fish and fillets, respectively). The employment of a much low temperature such as $-80^{\circ} \mathrm{C}$ 
showed a preservative effect by inhibiting lipid hydrolysis development, so that lower $(\mathrm{p}<0.05)$ FFA values were obtained in all cases by comparing $-80^{\circ} \mathrm{C}$ with $-20^{\circ} \mathrm{C}$ samples. The kind of product (whole fish and fillet) did not exert an important effect on lipid hydrolysis.

Examining the extent of lipid hydrolysis was deemed important to the study because of the high lipid hydrolysis development previously observed in horse mackerel during frozen storage (9) and also because of the great influence of lipid hydrolysis on lipid oxidation (31) and on protein denaturation (14).

\section{Lipid oxidation}

Peroxide formation (Table 3$)$ showed a higher $(\mathrm{p}<0.05)$ development for fillets at $-20^{\circ} \mathrm{C}$ than for the three other samples throughout the whole experiment that could be explained as a combination of a higher temperature and a higher surface exposure to air. At the end of the storage time, whole fish kept at $-20^{\circ} \mathrm{C}$ showed a big PV increase, so that higher $(\mathrm{p}<0.05)$ values than in the two $-80^{\circ} \mathrm{C}$ samples were assessed. In both fish products kept at $-80^{\circ} \mathrm{C}$ a peroxide breakdown could be assessed at the end of the experiment. Fair correlation values with time were obtained for samples kept at $-20^{\circ} \mathrm{C}$ $\left(r^{2}=0.82\right.$ and $r^{2}=0.74$, for whole fish and fillets, respectively). The employment of a low temperature such as $-80^{\circ} \mathrm{C}$ has inhibited the formation of peroxides, so that higher values than 12 were not obtained.

Secondary oxidation (Table 4) as measured by TBA-i showed similar results to the above mentioned peroxide values. A higher development in fillets kept at $-20^{\circ} \mathrm{C}$ was obtained showing a continuous increase with the storage time that led to a satisfactory correlation value $\left(r^{2}=0.94\right)$. The other three samples showed a maximum mean value at month 5 that was followed by a decrease. A higher $(\mathrm{p}<0.05)$ TBA-i was obtained for 
whole fish kept at $-20^{\circ} \mathrm{C}$ than for both products at $-80^{\circ} \mathrm{C}$ at the end of the storage time. Values obtained at $-20^{\circ} \mathrm{C}$ along the whole experiment were relatively low, compared to those related to fattier fish species (yellowfin tuna, swordfish and sardine) $(24,32)$.

Fluorescence formation (FR) showed a gradual increase for samples stored at $80^{\circ} \mathrm{C}$ and whole fish at $-20^{\circ} \mathrm{C}$ (Table 5). Best correlation values were obtained for the whole fish products $\left(\mathrm{r}^{2}=0.89\right.$ and $\mathrm{r}^{2}=0.92$, for $-80^{\circ} \mathrm{C}$ and $-20^{\circ} \mathrm{C}$ samples, respectively). This general increase can be explained as a result of interaction between peroxides and TBA reactive substances with nucleophilic molecules (free amino acids, peptides, proteins, aminated phospholipids) present in the fish muscle $(33,34)$ and leading to fluorescence active molecules. In the case of fillets stored at $-20^{\circ} \mathrm{C}$, a continuous increase was not observed, showing a decrease at month 5 and the highest mean value at month 9. According to the PV and TBA-i, a higher FR development for fillets at $-20^{\circ} \mathrm{C}$ than for the three other samples could be assessed along the whole storage time, while no significant differences $(p>0.05)$ could be obtained among the three others.

\section{$\underline{\text { Alpha-tocopherol assessment }}$}

Although a decreasing trend in alpha-tocopherol content was obtained for both samples kept at $-80^{\circ} \mathrm{C}$, no significant ( $\mathrm{p}>0.05$ ) differences could be assessed during the frozen storage (Table 6). However, samples kept at $-20^{\circ} \mathrm{C}$ showed a gradual content decrease in whole fish and fillet samples $\left(r^{2}=-0.73\right.$ and $r^{2}=-0.82$, respectively).

Comparison among the four kinds of samples led to a lower $(\mathrm{p}<0.05)$ content in fillets at $-20^{\circ} \mathrm{C}$ than in the three others at the end of the storage, according to the previously commented results on lipid oxidation (PV, TBA-i and FR). 
Present results show large individual variations in alpha-tocopherol content in accordance with previous research (35), that make it difficult to establish significant differences. However, the alpha-tocopherol mean value of whole fish kept at $-20^{\circ} \mathrm{C}$ was less than the corresponding values of both $-80^{\circ} \mathrm{C}$ samples at the end of the storage, although differences were not significant $(\mathrm{p}>0.05)$. Previous research where stronger processing conditions were applied, frozen storage at $-6^{\circ} \mathrm{C}(36)$ and frozen storage preceded by a previous chilling time (17) showed greater alpha-tocopherol losses than in the present case.

\section{$\underline{\text { Protein electrophoretic analysis }}$}

At month 7 of frozen storage, the fillets stored at $-20^{\circ} \mathrm{C}$ showed some changes in the sarcoplasmic protein profiles obtained from the low ionic strength buffer, according to the SDS-PAGE analysis (Figure 1). In this profile, one band (18 $\mathrm{kDa} \mathrm{MW}$ ) disappears from this date until the end of the trial. The same behavior can be observed in the case of whole fish stored $\mathrm{a}-20^{\circ} \mathrm{C}$ (months 9 and 12) and for the fillet samples at the end of the frozen storage at $-80^{\circ} \mathrm{C}$.

In the case of SDS soluble proteins, the analyses by $15 \%$ homogeneous SDSPAGE showed several changes in the protein profiles obtained. These changes are especially remarkable at the end of the storage (Figure 2) between 30-20 kDa and 20-14 $\mathrm{kDa}$ of molecular weight in whole fish and fillets kept frozen at $-20^{\circ} \mathrm{C}$, being the damage degree greater in the case of fillets than in whole fish. These two molecular weight ranges could correspond to different myosin light chains. Acrylamide concentration used in the present gels does not allow to separate proteins with a moleculear weight above $100 \mathrm{kDa}$, such as the myosin heavy chains. 
Under the effect of SDS, myosin molecule is known $(37,38)$ to dissociate into subunits of high and low molecular weight that can be separated by electrophoretic techniques. Thus, in the frozen state (38), there have been more changes in the electrophoretic profiles from SDS soluble proteins than in the sarcoplasmic fraction, as a result of being the myofibrillar fraction of seafoods most susceptible during the frozen storage. However, some low weight myofibrillar proteins can also be extracted with low ionic strength buffers, as the one employed in the present study. This kind of muscle proteins can be denatured by many factors such as temperature changes and the presence of oxidized lipids, formaldehyde, etc. In this kind of studies, SDS-PAGE has been widely used because it enables protein molecular weight determination and solubilization of denatured proteins (39).

\section{$\underline{\text { Sensory analysis }}$}

Marks obtained for the different kinds of samples throughout the experiment are indicated in Table 7. Since different sensory parameters were analyzed, in each kind of sample, Table 7 shows the lowest mark obtained at each sampling time.

Although a gradual acceptance decrease could be assessed for the four kinds of products during the experiment, damage rates were considerably different according to the storage temperature and to the kind of product, where fillets deteriorate faster than whole fish.

The sensory analysis showed a short shelf life for the fillets under $-20^{\circ} \mathrm{C}$; they were unacceptable at month 3 , while at $-20^{\circ} \mathrm{C}$ whole fish were still acceptable at month 5. In the case of whole fish, the limiting attribute appeared to be the rancid odor development, while for fillets it was both the rancid odor and yellowish color 
development. Both products kept at $-80^{\circ} \mathrm{C}$ tested as still edible at the end of the storage, since whole fish were good quality (A rang) and fillets were fair quality (B rang).

Sensory acceptance showed a good correlation with the storage time, specially in the case of samples kept at $-80^{\circ} \mathrm{C}\left(\mathrm{r}^{2}=0.87\right.$ and $\mathrm{r}^{2}=0.95$, whole fish and fillets, respectively). Comparison of sensory marks with biochemical indices showed the best correlation values for whole fish samples kept at $-80^{\circ} \mathrm{C}\left(\mathrm{r}^{2}=0.83\right.$ with $\left.\mathrm{FR}\right)$ and at $-20^{\circ} \mathrm{C}$ $\left(r^{2}=0.93\right.$ and $r^{2}=0.90$, with FFA and FR, respectively).

\section{FINAL COMMENTS}

According to sensory assessment, frozen horse mackerel as a fillet product has shown a short shelf life (1 month) when stored at a commercial temperature $\left(-20^{\circ} \mathrm{C}\right)$; however, whole fish products were shown to maintain a longer shelf life, being edible at month 5. These results agreed with biochemical indices related to lipid oxidation development (PV, TBA-i, FR), endogenous antioxidant loss (alpha-tocopherol) and SDS soluble protein fraction, but not with lipid hydrolysis formation, where no effect of the product type was observed. The employment of the much low temperature of $-80^{\circ} \mathrm{C}$ was shown to prevent rancidity development, although its use is not interesting because of commercial expenses.

In the case that longer shelf life times are commercially required (for fillets, especially), protective treatments such as vacuum packaging, modified atmosphere packaging and natural antioxidant application $(40,41)$ are recommended to prevent lipid oxidation development and accordingly its effects on sensory acceptance, myofibrillar profile changes and endogenous antioxidant loss. 
$\underline{\text { Acknowledgements }}$

The authors thank Mr. Marcos Trigo and Mrs. Janet Ares for technical assistance and are grateful for the financial support provided by the Comisión Interministerial de Ciencia y Tecnología (CICyT) through the Project ALI 99-0869 (2000-2002). 


\section{REFERENCES}

1 Kinsella, J., Dietary fats and cardiovascular disease, in Seafoods and fish oils in human health and disease, edited by R. Lees, M. Karel, Marcel Dekker, Inc., New York (USA), 1987, pp. 1-23.

2 Illingworth, D., and D. Ullmann, Effects of omega-3 fatty acids on risk factors for cardiovascular disease, in Omega-3 fatty acids in health and disease, edited by R. Lees, M. Karel, Marcel Dekker, Inc., New York (USA) and Basel (Switzerland), 1990, pp. 39-69.

3 Flick, G., A. Bimbo, L. Enríquez, and R. Ory, Potential and physical properties of underutilized species, menhaden, in Advances in seafood biochemistry. Composition and quality, edited by G. Flick, D. Kitts, Technomic, Publishing Co., Inc., Lancaster, PA (USA), 1992, pp. 1-23.

4 Shahidi, F., and V. Venugopal, Water-soluble protein preparative from underutilized fish species, in Seafood safety, processing and biotechnology, edited by F. Shahidi, Y. Jones, D. Kitts, Technomic, Publishing Co., Inc., Lancaster, PA (USA), 1997, pp. 181-186.

5 FAO, Fishery statistics, Yearbook 2000, Vol. 90/1. Food and Agriculture Organization of the United Nations, Rome (Italy), 2002, pp. 245-248.

6 García, I., B. Pérez-Villarreal, and R. Pozo, Valorización de especies pesqueras infrautilizadas. Alimentación, Equipos y Tecnología, January/February: 145-149 (1996).

7 Münkner, W., Zur rationellen Verwertung der Rohware Fisch. II. Die Konservenherstellung aus Fischfarsch. Fischerei-Forschung Rostock 25: 120122 (1987). 
8 Aubourg, S., Damage detection in horse mackerel (Trachurus trachurus) during chilled storage. JAOCS 78: 857-862 (2001).

9 Aubourg, S., I. Lehmann, and J. Gallardo, Effect of previous chilled storage on rancidity development in frozen horse mackerel (Trachurus trachurus). J. Sci. Food Agric. 82: 1764-1771 (2002).

10 Pigott, G., and B. Tucker, Science opens new horizons for marine lipids in human nutrition. Food Rev. Internat. 3: 105-138 (1987).

11 Erickson, M., Lipid oxidation: Flavor and Nutritional Quality Deterioration in Frozen Foods, in Quality in Frozen Food, edited by M. Erickson, Y.-C. Hung, Chapman \& Hall, New York (USA), 1997, pp. 141-173.

12 Mohri, S., S. Y. Cho, Y. Endo, and K. Fujimoto, Linoleate 13(S)-lipoxygenase in sardine skin. J. Agric. Food Chem. 40: 573-576 (1992).

13 Richards, M., and H. Hultin, Contributions of blood and blood components to lipid oxidation in fish muscle. J. Agric. Food Chem. 50: 555-564 (2002).

14 Sikorski, Z., and A. Kolakowska, Changes in protein in frozen stored fish, in Seafood proteins, edited by Z. Sikorski, B. Sun Pan, and F. Shahidi, Chapman and Hall, New York (USA), 1994, pp. 99-112.

15 Castrillón, A., E. Álvarez-Pontes, M. García, and P. Navarro, Influence of frozen storage and defrosting on the chemical and nutritional quality of sardine (Clupea pilchardus). J. Sci. Food Agric. 70: 29-34 (1996).

16 Saeed, S., and N. Howell, Effect of lipid oxidation and frozen storage on muscle proteins of Atlantic mackerel (Scomber scombrus). J. Sci. Food Agric. 82: 579$586(2002)$. 
17 Undeland, I., and H. Lingnert, Lipid oxidation in fillets of herring (Clupea harengus) during frozen storage. Influence of prefreezing storage. J. Agric. Food Chem. 47: 2075-2081 (1999).

18 Council Regulations, Baremo de Clasificación de Frescura, in Diario Oficial de las Comunidades Europeas. European Commission, Brussels (Belgium), No. L 5/21, 1989, pp. 5-6.

19 Bligh, E., and W. Dyer, A rapid method of total extraction and purification. Can. J. Biochem. Physiol. 37: 911-917 (1959).

20 Piñeiro, C., J. Barros-Velázquez, R. Pérez-Martín, I. Martínez, T. Jacobsen, H. Rehbein, R. Kündiger, R. Mendes, M. Ettienne, M. Jerome, A. Craig, I. Mackie, and F. Jessen, Development of a sodium dodecyl sulfate-polyacrylamide gel electrophoresis reference method for the analysis and identification of fish species in raw and heat-processed samples: A collaborative study. Electrophoresis 20: 1425-1432 (1999).

21 Lowry, R., and I. Tinsley, Rapid colorimetric determination of free fatty acids. JAOCS 53: 470-472 (1976).

22 Chapman, R., and J. McKay, The estimation of peroxides in fats and oils by the ferric thiocyanate method. JAOCS 26: 360-363 (1949).

23 Vyncke, W., Direct determination of the thiobarbituric acid value in trichloracetic acid extracts of fish as a measure of oxidative rancidity. Fette Seifen Anstrichm. 72: 1084-1087 (1970).

24 Aubourg, S., C. Sotelo, and R. Pérez-Martín, Assessment of quality changes in frozen sardine (Sardina pilchardus) by fluorescence detection. JAOCS 75: 575580 (1998). 
25 Aubourg, S., Lipid damage detection during the frozen storage of an underutilized fish species. Food Res. Internat. 32: 497-502 (1999).

26 Cabrini, L., L. Landi, C. Stefanelli, V. Barzanti, and M. Sechi, Extraction of lipid and lipophilic antioxidants from fish tissues: A comparison among different methods. Comp. Biochem. Physiol. B. Biochem. Molec. Biol. 101: 383-386 (1992).

27 Laemmli, U., Cleavage of structure proteins during the assembly of the head of bacteriophage T4. Nature 227: 680-685 (1970).

28 Statsoft, Statistica for Macintosh. Statsoft and its licensors, Tulsa, Oklahoma (USA), 1994.

29 Aubourg, S., and I. Medina, Influence of storage time and temperature on lipid deterioration during cod (Gadus morhua) and haddock (Melanogrammus aeglefinus) frozen storage. J. Sci. Food Agric. 79: 1943-1948 (1999).

30 Medina, I., R. Sacchi, and S. Aubourg, A ${ }^{13}$ C-NMR study of lipid alterations during fish canning: Effect of filling medium. J. Sci. Food Agric. 69: 445-450 (1995).

31 Yoshida, H., I. Kondo, G. Kajimoto, Participation of free fatty acids in the oxidation of purified soybean oil during microwave heating. JAOCS 69: 1136-1140 (1992).

32 Kurade, S., and J. Baranowski, Prediction of shelf life of frozen minced fish in terms of oxidative rancidity as measured by TBARS number. J. Food Sci. 52: 300-302, 311 (1987).

33 Leake, L., and M. Karel, Nature of fluorescent compounds generated by exposure of protein to oxidizing lipids. J. Food Biochem. 9: 117-136 (1985). 
34 Kikugawa, K., and M. Beppu, Involvement of lipid oxidation products in the formation of fluorescent and cross-linked proteins. Chem. Phys. Lipids 44: 277297 (1987).

35 Undeland, I., B. Ekstrand, and H. Lingnert, Lipid oxidation in herring (Clupea harengus) light muscle, dark muscle, and skin, stored separately or as intact fillets. JAOCS 75: 581-590 (1998).

36 Brannan, R., and M. Erickson, Quantification of antioxidants in channel catfish during frozen storage. J. Agric. Food Chem. 44: 1361-1366 (1996).

37 Sikorski, Z., Muscle proteins. In Chemical-Functional Properties of Food Proteins, edited by Z. Sikorski, Technomic Publishing Co., Inc., Basel (Switzerland), 2001, pp. 233-268.

38 Sikorski, Z., The myofibrillar proteins in seafood. In Seafood Proteins, edited by Z. Sikorski, B. Sun Pan, F. Shahidi, Chapman \& Hall, New York (USA), 1994, pp. $40-57$.

39 Sotelo, C., C. Piñeiro, R. Pérez-Martin, and J. Gallardo, Analysis of fish and squid myofibrillar proteins by capillary sodium dodecyl sulfate gel electrophoresis: actin and myosin quantification. Eur. Food Res. Technol. 211: 443-448 (2000).

40 Toledo-Flores, L., and R. Zall, Methods for extending the storage life of fresh tropical fish, in Advances in Seafood Biochemistry, edited by G. Flick, R. Martin, Technomic Publishing, Lancaster, PA (USA), 1992, 233-243.

41 Richards, M., S. Kelleher, and H. Hultin, Effect of washing with or without antioxidants on quality retention of mackerel fillets during refrigerated and frozen storage. J. Agric. Food Chem. 46: 4363-4371 (1998). 


\section{FIGURE LEGENDS}

Figure 1: Electrophoretic profiles* obtained from analyses of sarcoplasmic protein fraction by SDS-PAGE in commercial homogeneous gels.

* Lanes abbreviations: ST (low molecular weight standard), 0 (raw fish), W-80 (whole fish stored at $-80^{\circ} \mathrm{C}$ ), $\mathbf{W}-20$ (whole fish stored at $-20^{\circ} \mathrm{C}$ ), $\mathbf{F}-80$ (fillets stored at $-80^{\circ} \mathrm{C}$ ), F-20 (fillets stored at $-20^{\circ} \mathrm{C}$ ). The numbers above the lanes indicate the months of frozen storage. The cathodic (-) and anodic $(+)$ sides are indicated.

Figure 2: Electrophoretic profiles* obtained from analyses of SDS-soluble muscle proteins and separated in SDS-PAGE commercial homogeneous (15\%) gels.

* Lanes abbreviations: ST (low molecular weight standard), 0 (raw fish), W-80 (whole fish stored at $-80^{\circ} \mathrm{C}$ ), $\mathbf{W}-20$ (whole fish stored at $-20^{\circ} \mathrm{C}$ ), $\mathbf{F}-80$ (fillets stored at $-80^{\circ} \mathrm{C}$ ), F-20 (fillets stored at $-20^{\circ} \mathrm{C}$ ). The numbers above the lanes indicate the months of frozen storage. The cathodic $(-)$ and anodic $(+)$ sides are indicated. 
TABLE 1

Scale employed for evaluating quality of frozen horse mackerel

\begin{tabular}{|c|c|c|c|c|}
\hline Attribute & $\begin{array}{c}\text { E } \\
\text { (Highest } \\
\text { quality) }\end{array}$ & $\begin{array}{c}\text { A } \\
\text { (Good quality) }\end{array}$ & $\begin{array}{c}\text { B } \\
\text { (Fair quality) }\end{array}$ & $\begin{array}{c}\text { C } \\
\text { (Rejectable } \\
\text { quality) }\end{array}$ \\
\hline Skin & $\begin{array}{l}\text { Very intense } \\
\text { pigmentation; } \\
\text { transparent } \\
\text { mucus }\end{array}$ & $\begin{array}{l}\text { Insignificant } \\
\text { pigmentation } \\
\text { losses; slightly } \\
\text { turbid mucus } \\
\end{array}$ & $\begin{array}{l}\text { Pigmentation } \\
\text { discolored and } \\
\text { without shine; } \\
\text { milky mucus }\end{array}$ & $\begin{array}{c}\text { Important } \\
\text { pigmentation } \\
\text { losses; opaque } \\
\text { mucus }\end{array}$ \\
\hline Eyes & $\begin{array}{c}\text { Convex; } \\
\text { transparent } \\
\text { cornea; bright } \\
\text { and black pupil }\end{array}$ & $\begin{array}{c}\text { Convex and } \\
\text { slightly sunken; } \\
\text { slightly } \\
\text { opalescent } \\
\text { cornea; black } \\
\text { and cloudy } \\
\text { pupil }\end{array}$ & $\begin{array}{c}\text { Flat; opalescent } \\
\text { cornea; opaque } \\
\text { pupil }\end{array}$ & $\begin{array}{c}\text { Concave and } \\
\text { milky cornea; } \\
\text { gray pupil }\end{array}$ \\
\hline Gills & $\begin{array}{c}\text { Bright red; } \\
\text { without odor; } \\
\text { lamina perfectly } \\
\text { separated }\end{array}$ & $\begin{array}{l}\text { Rose-colored; } \\
\text { without odor; } \\
\text { lamina adhered } \\
\text { in groups }\end{array}$ & $\begin{array}{l}\text { Slightly pale; } \\
\text { fishy odor; } \\
\text { lamina adhered } \\
\text { in groups }\end{array}$ & $\begin{array}{l}\text { Grey-yellowish } \\
\text { color; intense } \\
\text { ammonia odor; } \\
\text { lamina totally } \\
\text { adhered } \\
\end{array}$ \\
\hline Flesh odor & $\begin{array}{c}\text { Sharply } \\
\text { seaweedy and } \\
\text { shellfish }\end{array}$ & $\begin{array}{c}\text { Weakly } \\
\text { seaweedy and } \\
\text { shellfish }\end{array}$ & $\begin{array}{l}\text { Slightly sour } \\
\text { and incipient } \\
\text { rancidity }\end{array}$ & $\begin{array}{l}\text { Sharply sour } \\
\text { and rancid }\end{array}$ \\
\hline Consistency & $\begin{array}{l}\text { Presence or } \\
\text { partial } \\
\text { disappearance } \\
\text { of rigor mortis } \\
\text { symptoms } \\
\end{array}$ & $\begin{array}{c}\text { Firm and } \\
\text { elastic; pressure } \\
\text { signs disappear } \\
\text { immediately } \\
\text { and completely } \\
\end{array}$ & $\begin{array}{c}\text { Presence of } \\
\text { mechanical } \\
\text { signs; elasticity } \\
\text { notably reduced }\end{array}$ & $\begin{array}{l}\text { Important shape } \\
\text { changes due to } \\
\text { mechanical } \\
\text { factors }\end{array}$ \\
\hline $\begin{array}{c}\text { Flesh } \\
\text { appearance }\end{array}$ & $\begin{array}{c}\text { Strongly } \\
\text { hydrated and } \\
\text { pinky; } \\
\text { myotomes } \\
\text { totally adhered }\end{array}$ & $\begin{array}{l}\text { Still hydrated } \\
\text { and pinky; } \\
\text { myotomes } \\
\text { adhered }\end{array}$ & $\begin{array}{l}\text { Slightly dry and } \\
\text { pale; myotomes } \\
\text { adhered in } \\
\text { groups }\end{array}$ & $\begin{array}{l}\text { Yellowish and } \\
\text { dry; myotomes } \\
\text { totally separated }\end{array}$ \\
\hline
\end{tabular}




\section{TABLE 2}

Free fatty acid (FFA)* determination in frozen horse mackerel**

\begin{tabular}{|c|c|c|c|c|}
\hline $\begin{array}{c}\text { Frozen } \\
\text { Storage Time } \\
\text { (months) }\end{array}$ & WP-80 & WP-20 & F-80 & F-20 \\
\hline Raw Fish & $\begin{array}{c}0.60 \mathrm{a} \\
(0.290)\end{array}$ & $\begin{array}{c}0.60 \mathrm{a} \\
(0.290)\end{array}$ & $\begin{array}{c}0.60 \mathrm{ab} \\
(0.290)\end{array}$ & $\begin{array}{c}0.60 \mathrm{a} \\
(0.290)\end{array}$ \\
\hline 1 & $\begin{array}{c}{ }^{\mathrm{W}} 0.35 \mathrm{a} \\
(0.153)\end{array}$ & $\begin{array}{c}\mathrm{X} 1.20 \mathrm{a} \\
(0.404)\end{array}$ & $\begin{array}{c}{ }^{\mathrm{W}} 0.61 \mathrm{ab} \\
(0.184)\end{array}$ & $\begin{array}{c}\mathrm{Y} 1.92 \mathrm{ab} \\
(0.104)\end{array}$ \\
\hline 3 & $\begin{array}{c}\mathrm{w}_{0.39} \mathrm{a} \\
(0.116)\end{array}$ & $\begin{array}{c}2.47 \mathrm{ab} \\
(0.528)\end{array}$ & $\begin{array}{c}\mathrm{w}^{\mathrm{N}} 0.57 \mathrm{a} \\
(0.260)\end{array}$ & $\begin{array}{c}\mathrm{X} 3.22 \mathrm{~b} \\
(0.696)\end{array}$ \\
\hline 5 & $\begin{array}{c}1.10 \mathrm{~b} \\
(0.290)\end{array}$ & $\begin{array}{c}\mathrm{X} 3.75 \text { bc } \\
(0.575)\end{array}$ & $\begin{array}{c}1.27 \mathrm{~b} \\
(0.226)\end{array}$ & $\begin{array}{c}\times 3.78 \text { b } \\
(0.469)\end{array}$ \\
\hline 7 & $\begin{array}{c}{ }^{\mathrm{W}} 0.73 \mathrm{a} \\
(0.221)\end{array}$ & $\begin{array}{c}\mathrm{Y} 5.85 \mathrm{~cd} \\
(1.584)\end{array}$ & $\begin{array}{c}0.66 \mathrm{ab} \\
(0.252)\end{array}$ & $\begin{array}{c}\mathrm{X} 3.99 \mathrm{~b} \\
(1.069)\end{array}$ \\
\hline 9 & $\begin{array}{c}\text { W } 0.58 \text { a } \\
(0.198)\end{array}$ & $\begin{array}{c}x 8.35 \mathrm{de} \\
(2.428)\end{array}$ & $\begin{array}{c}\text { W } 1.24 \text { b } \\
(0.424)\end{array}$ & $\begin{array}{c}\mathrm{X} 6.67 \mathrm{c} \\
(2.191)\end{array}$ \\
\hline 12 & $\begin{array}{c}{ }^{\mathrm{W}} 0.37 \mathrm{a} \\
(0.200)\end{array}$ & $\begin{array}{c}\mathrm{X} 10.09 \mathrm{e} \\
(2.001)\end{array}$ & $\begin{array}{c}{ }^{\mathrm{W}} 0.57 \mathrm{a} \\
(0.411)\end{array}$ & $\begin{array}{c}{ }^{x} 8.30 \mathrm{c} \\
(2.056)\end{array}$ \\
\hline
\end{tabular}

* Expressed as g FFA/100g lipids. Mean values of three independent determinations; standard deviations are indicated in brackets. For each column, means followed by different letters $(a-e)$ are significantly different $(p<0.05)$. For each row, means preceded by different superscripts $(\mathrm{w}-\mathrm{y})$ are significantly different $(\mathrm{p}<0.05)$.

** Sample abbreviations: WP-80 (whole fish stored at $-80^{\circ} \mathrm{C}$ ), WP-20 (whole fish stored at $-20^{\circ} \mathrm{C}$ ), F-80 (fillets stored at $-80^{\circ} \mathrm{C}$ ) and $\mathrm{F}-20$ (fillets stored at $-20^{\circ} \mathrm{C}$ ). 


\section{TABLE 3}

Peroxide value* assessment in frozen horse mackerel**

\begin{tabular}{|c|c|c|c|c|}
\hline $\begin{array}{c}\text { Frozen } \\
\text { Storage Time } \\
\text { (months) }\end{array}$ & WP-80 & WP-20 & F-80 & F-20 \\
\hline Raw Fish & $\begin{array}{l}3.59 \mathrm{ab} \\
(0.283)\end{array}$ & $\begin{array}{l}3.59 \mathrm{ab} \\
(0.283)\end{array}$ & $\begin{array}{l}3.59 \mathrm{a} \\
(0.283)\end{array}$ & $\begin{array}{l}3.59 \mathrm{a} \\
(0.283)\end{array}$ \\
\hline 1 & $\begin{array}{c}{ }^{\mathrm{w}} 3.09 \mathrm{a} \\
(1.179)\end{array}$ & $\begin{array}{c}{ }^{\mathrm{W}} 2.68 \mathrm{a} \\
(0.635)\end{array}$ & $\begin{array}{c}\text { W } 3.97 \mathrm{a} \\
(1.796)\end{array}$ & $\begin{array}{c}\mathrm{X}^{2} 16.02 \mathrm{~b} \\
(1.758)\end{array}$ \\
\hline 3 & $\begin{array}{c}8.13 \mathrm{~cd} \\
(0.294)\end{array}$ & $\begin{array}{l}10.14 \mathrm{abc} \\
(2.825)\end{array}$ & $\begin{array}{l}{ }^{w} 4.32 \mathrm{a} \\
(1.382)\end{array}$ & $\begin{array}{c}58.26 \mathrm{e} \\
(2.616)\end{array}$ \\
\hline 5 & $\begin{array}{c}9.35 \mathrm{~cd} \\
(2.747)\end{array}$ & $\begin{array}{c}9.87 \mathrm{abc} \\
(2.744)\end{array}$ & $\begin{array}{l}{ }^{w} 4.56 \mathrm{a} \\
(1.150)\end{array}$ & $\begin{array}{l}33.63 \mathrm{~cd} \\
(7.637)\end{array}$ \\
\hline 7 & $\begin{array}{c}\mathrm{wx} 8.62 \mathrm{~cd} \\
(0.939)\end{array}$ & $\begin{array}{c}x 14.48 \mathrm{c} \\
(4.326)\end{array}$ & $\begin{array}{c}7.44 \mathrm{~b} \\
(1.293)\end{array}$ & $\begin{array}{c}\mathrm{Y} 26.86 \mathrm{c} \\
(0.623)\end{array}$ \\
\hline 9 & $\begin{array}{c}11.49 \mathrm{~d} \\
(3.130)\end{array}$ & $\begin{array}{l}12.63 \mathrm{bc} \\
(4.050)\end{array}$ & $\begin{array}{c}10.92 \mathrm{c} \\
(1.343)\end{array}$ & $\begin{array}{c}x 39.33 \mathrm{~d} \\
(6.010)\end{array}$ \\
\hline 12 & $\begin{array}{c}{ }^{w} 6.63 \mathrm{bc} \\
(2.036)\end{array}$ & $\begin{array}{c}\mathrm{x} 31.77 \mathrm{~d} \\
(1.676)\end{array}$ & $\begin{array}{c}\text { w } 3.84 \mathrm{a} \\
(0.987)\end{array}$ & $\begin{array}{c}\mathrm{Y}^{\mathrm{Y}} 87.44 \mathrm{f} \\
(10.709)\end{array}$ \\
\hline
\end{tabular}

* Expressed as meq oxygen/kg lipids. Mean values of three independent determinations; standard deviations are indicated in brackets. For each column, means followed by different letters $(a-f)$ are significantly different $(p<0.05)$. For each row, means preceded by different superscripts $(\mathrm{w}-\mathrm{y})$ are significantly different $(\mathrm{p}<0.05)$.

** Sample abbreviations as specified in Table 2. 


\section{TABLE 4}

Thiobarbituric acid index* determination in frozen horse mackerel**

\begin{tabular}{|c|c|c|c|c|}
\hline $\begin{array}{c}\text { Frozen } \\
\text { Storage Time } \\
\text { (months) }\end{array}$ & WP-80 & WP-20 & F-80 & F-20 \\
\hline Raw Fish & $\begin{array}{l}0.17 \mathrm{a} \\
(0.035)\end{array}$ & $\begin{array}{l}0.17 \mathrm{a} \\
(0.035)\end{array}$ & $\begin{array}{c}0.17 \mathrm{a} \\
(0.035)\end{array}$ & $\begin{array}{c}0.17 \mathrm{a} \\
(0.035)\end{array}$ \\
\hline 1 & $\begin{array}{c}{ }^{\mathrm{W}} 0.19 \mathrm{a} \\
(0.083)\end{array}$ & $\begin{array}{c}{ }^{\mathrm{W}} 0.26 \mathrm{ab} \\
(0.129)\end{array}$ & $\begin{array}{c}{ }^{\mathrm{w}} 0.24 \mathrm{a} \\
(0.051)\end{array}$ & $\begin{array}{c}{ }^{\mathrm{X}} 0.76 \mathrm{~b} \\
(0.190)\end{array}$ \\
\hline 3 & $\begin{array}{c}{ }^{w} 0.19 \text { a } \\
(0.085)\end{array}$ & $\begin{array}{c}{ }^{x} 0.41 \mathrm{~b} \\
(0.113)\end{array}$ & $\begin{array}{c}{ }^{x} 0.45 \mathrm{~b} \\
(0.136)\end{array}$ & $\begin{array}{c}1.04 \mathrm{bc} \\
(0.110)\end{array}$ \\
\hline 5 & $\begin{array}{c}{ }^{\mathrm{W}} 0.72 \mathrm{~b} \\
(0.162)\end{array}$ & $\begin{array}{c}{ }^{\mathrm{W}} 0.85 \mathrm{c} \\
(0.050)\end{array}$ & $\begin{array}{c}{ }^{\mathrm{W}} 0.83 \mathrm{c} \\
(0.170)\end{array}$ & $\begin{array}{c}{ }^{\mathrm{W}} 0.74 \mathrm{~b} \\
(0.089)\end{array}$ \\
\hline 7 & $\begin{array}{c}{ }^{\mathrm{w}} 0.18 \mathrm{a} \\
(0.051)\end{array}$ & $\begin{array}{c}{ }^{\mathrm{X}} 0.45 \mathrm{~b} \\
(0.151)\end{array}$ & $\begin{array}{c}{ }^{\mathrm{w}} 0.20 \mathrm{a} \\
(0.081)\end{array}$ & $\begin{array}{c}\mathrm{Y} 1.29 \mathrm{~cd} \\
(0.056)\end{array}$ \\
\hline 9 & $\begin{array}{c}{ }^{\mathrm{W}} 0.22 \mathrm{a} \\
(0.040)\end{array}$ & $\begin{array}{c}{ }^{\mathrm{w}} 0.41 \mathrm{~b} \\
(0.145)\end{array}$ & $\begin{array}{c}{ }^{\mathrm{W}} 0.20 \mathrm{a} \\
(0.095)\end{array}$ & $\begin{array}{c}{ }^{x} 1.60 \mathrm{~d} \\
(0.406)\end{array}$ \\
\hline 12 & $\begin{array}{c}{ }^{\mathrm{W}} 0.22 \mathrm{a} \\
(0.069)\end{array}$ & $\begin{array}{c}{ }^{X} 0.75 \mathrm{c} \\
(0.190)\end{array}$ & $\begin{array}{c}{ }^{\mathrm{w}} 0.14 \mathrm{a} \\
(0.012)\end{array}$ & $\begin{array}{c}\mathrm{Y}^{\mathrm{2}} 2.37 \mathrm{e} \\
(0.167)\end{array}$ \\
\hline
\end{tabular}

* Expressed as mg malondialdehyde/kg fish muscle. Mean values of three independent determinations; standard deviations are indicated in brackets. For each column, means followed by different letters $(a-e)$ are significantly different $(p<0.05)$. For each row, means preceded by different superscripts (w-y) are significantly different $(\mathrm{p}<0.05)$.

** Sample abbreviations as specified in Table 2. 


\section{TABLE 5}

Fluorescence ratio* analysis in frozen horse mackerel**

\begin{tabular}{|c|c|c|c|c|}
\hline $\begin{array}{l}\text { Frozen } \\
\text { Storage Time } \\
\text { (months) }\end{array}$ & WP-80 & WP-20 & F-80 & F-20 \\
\hline Raw Fish & $\begin{array}{l}0.42 \mathrm{a} \\
(0.015)\end{array}$ & $\begin{array}{l}0.42 \mathrm{a} \\
(0.015)\end{array}$ & $\begin{array}{c}0.42 \mathrm{a} \\
(0.015)\end{array}$ & $\begin{array}{c}0.42 \mathrm{a} \\
(0.015)\end{array}$ \\
\hline 1 & $\begin{array}{l}0.52 \mathrm{ab} \\
(0.71)\end{array}$ & $\begin{array}{c}0.70 \mathrm{~b} \\
(0.112)\end{array}$ & $\begin{array}{l}{ }^{\mathrm{W}} 0.53 \mathrm{a} \\
(0.028)\end{array}$ & $\begin{array}{c}\mathrm{X} 1.45 \mathrm{bc} \\
(0.331)\end{array}$ \\
\hline 3 & $\begin{array}{l}0.65 \mathrm{ab} \\
(0.028)\end{array}$ & $\begin{array}{c}0.89 \text { b } \\
(0.223)\end{array}$ & $\begin{array}{c}{ }^{\mathrm{W}} 0.53 \mathrm{a} \\
(0.072)\end{array}$ & $\begin{array}{c}x 1.79 \mathrm{~cd} \\
(0.291)\end{array}$ \\
\hline 5 & $\begin{array}{c}0.79 \mathrm{~b} \\
(0.146)\end{array}$ & $\begin{array}{c}0.73 \text { b } \\
(0.157)\end{array}$ & $\begin{array}{c}\text { WX } 1.10 \text { bc } \\
(0.346)\end{array}$ & $\begin{array}{c}\mathrm{X} 1.35 \mathrm{~b} \\
(0.304)\end{array}$ \\
\hline 7 & $\begin{array}{c}{ }^{\mathrm{W}} 0.83 \mathrm{bc} \\
(0.014)\end{array}$ & $\begin{array}{l}{ }^{X} 1.14 \mathrm{c} \\
(0.133)\end{array}$ & $\begin{array}{c}\text { WX } 1.01 \mathrm{bc} \\
(0.031)\end{array}$ & $\begin{array}{c}\mathrm{Y} 1.38 \mathrm{bc} \\
(0.145)\end{array}$ \\
\hline 9 & $\begin{array}{c}1.16 \mathrm{~cd} \\
(0.349)\end{array}$ & $\begin{array}{c}1.19 \mathrm{~cd} \\
(0.085)\end{array}$ & $\begin{array}{c}\text { W } 0.85 \text { b } \\
(0.184)\end{array}$ & $\begin{array}{c}x 1.90 \mathrm{~d} \\
(0.246)\end{array}$ \\
\hline 12 & $\begin{array}{c}{ }^{\mathrm{W}} 1.28 \mathrm{~d} \\
(0.134)\end{array}$ & $\begin{array}{l}{ }^{\mathrm{W}} 1.43 \mathrm{~d} \\
(0.100)\end{array}$ & $\begin{array}{l}\text { W } 1.14 \mathrm{c} \\
(0.201)\end{array}$ & $\begin{array}{c}X 1.80 \mathrm{~cd} \\
(0.248)\end{array}$ \\
\hline
\end{tabular}

* Calculated as expressed in the Materials and Methods section. Mean values of three independent determinations; standard deviations are indicated in brackets. For each column, means followed by different letters (a-d) are significantly different $(\mathrm{p}<0.05)$. For each row, means preceded by different superscripts $(w-y)$ are significantly different $(\mathrm{p}<0.05)$.

** Sample abbreviations as specified in Table 2. 


\section{TABLE 6}

Alpha-tocopherol* assessment in frozen horse mackerel**

\begin{tabular}{|c|c|c|c|c|}
\hline $\begin{array}{c}\text { Frozen } \\
\text { Storage Time } \\
\text { (months) }\end{array}$ & WP-80 & WP-20 & F-80 & F-20 \\
\hline Raw Fish & $\begin{array}{l}308.33 \mathrm{a} \\
(97.787)\end{array}$ & $\begin{array}{c}308.33 \mathrm{~b} \\
(97.787)\end{array}$ & $\begin{array}{c}308.33 \mathrm{ab} \\
(97.787)\end{array}$ & $\begin{array}{l}308.33 \mathrm{c} \\
(97.787)\end{array}$ \\
\hline 1 & $\begin{array}{c}326.67 \mathrm{a} \\
(23.072)\end{array}$ & $\begin{array}{c}356.33 \mathrm{~b} \\
(87.077)\end{array}$ & $\begin{array}{c}304.33 \mathrm{ab} \\
(143.615)\end{array}$ & $\begin{array}{c}\text { W } 319.67 \mathrm{c} \\
(81.684)\end{array}$ \\
\hline 3 & $\begin{array}{c}{ }^{w} 289.0 \mathrm{a} \\
(12.490)\end{array}$ & $\begin{array}{c}350.67 \mathrm{~b} \\
(60.343)\end{array}$ & $\begin{array}{c}328.17 \mathrm{~b} \\
(73.141)\end{array}$ & $\begin{array}{l}225.67 \mathrm{bc} \\
(36.747)\end{array}$ \\
\hline 5 & $\begin{array}{l}\text { W } 273.0 \mathrm{a} \\
(29.103)\end{array}$ & $\begin{array}{l}260.47 \mathrm{ab} \\
(42.211)\end{array}$ & $\begin{array}{l}306.67 \mathrm{ab} \\
(81.938)\end{array}$ & $\begin{array}{l}201.00 \text { bc } \\
(43.486)\end{array}$ \\
\hline 7 & $\begin{array}{c}225.43 \mathrm{a} \\
(41.373)\end{array}$ & $\begin{array}{c}161.67 \mathrm{a} \\
(10.786)\end{array}$ & $\begin{array}{c}221.47 \mathrm{a} \\
(30.293)\end{array}$ & $\begin{array}{l}188.47 \text { bc } \\
(31.490)\end{array}$ \\
\hline 9 & $\begin{array}{c}225.50 \mathrm{a} \\
(68.891)\end{array}$ & $\begin{array}{c}188.60 \mathrm{a} \\
(16.122)\end{array}$ & $\begin{array}{r}133.93 \mathrm{a} \\
(5.090)\end{array}$ & $\begin{array}{c}93.75 \mathrm{ab} \\
(47.023)\end{array}$ \\
\hline 12 & $\begin{array}{c}\mathrm{X} 237.33 \mathrm{a} \\
(45.927)\end{array}$ & $\begin{array}{cc}\mathrm{X} & 161.93 \mathrm{a} \\
(53.421)\end{array}$ & $\begin{array}{l}\mathrm{X} 214.00 \mathrm{a} \\
(75.530)\end{array}$ & $\begin{array}{c}28.13 \mathrm{a} \\
(9.381)\end{array}$ \\
\hline
\end{tabular}

* Expressed as microg/100g fish muscle. Mean values of three independent determinations; standard deviations are indicated in brackets. For each column, means followed by different letters $(a-c)$ are significantly different $(p<0.05)$. For each row, means preceded by different superscripts $(\mathrm{w}-\mathrm{x})$ are significantly different $(\mathrm{p}<0.05)$.

** Sample abbreviations as specified in Table 2. 
TABLE 7

Sensory acceptance* of frozen horse mackerel**

\begin{tabular}{|c|c|c|c|c|}
\hline $\begin{array}{c}\text { Frozen Storage } \\
\text { Time } \\
\text { (months) }\end{array}$ & WP-80 & WP-20 & F-80 & F-20 \\
\hline Raw Fish & E & E & E & E \\
\hline 1 & E & A & E & B \\
\hline 3 & E & B & A & C \\
\hline 5 & A & B & A & C \\
\hline 7 & A & C & A & C \\
\hline 9 & A & C & B & C \\
\hline 12 & A & C & B & C \\
\hline
\end{tabular}

* Category marks according to Table 1.

** Sample abbreviations as specified in Table 2. 